\title{
FRIEDRICH RÜCKERT: KINDERTODTENLIEDER
}

\section{FRIEDRICH RÜCKERT: KINDERTODTENLIEDER}

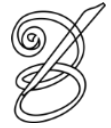 \\ Daniel MARTINESCHEN ${ }^{*}$ \\ Universidade Federal de Santa Catarina \\ Florianópolis, Santa Catarina, Brasil
}

Resumo: Friedrich Rückert (1788-1866) foi um poeta e tradutor do Romantismo alemão. Erudito autodidata e poliglota, traduziu muitos textos de muitas línguas do Oriente Médio, entre eles o Corão, poesia persa, turca e árabe. Sua própria poesia é fortemente influenciada por seu trabalho de tradutor e estudioso da literatura oriental. Sua obra mais famosa, Kindertodtenlieder, musicada por Gustav Mahler, dá corpo poético à dor da perda de seus dois filhos mais novos em tenra idade para a escarlatina. Apresentamos aqui quatro desses poemas em tradução inédita ao português.

Palavras-chave: Friedrich Rückert. Romantismo. Poesia.

Abstract: Friedrich Rückert (1788-1866) was a German Romantic poet and translator. A self-taught scholar and polyglot, he translated many works from many languages of the Middle East, such as the Koran, poetry in Persian, Turkish and Arabic. His own poetry reveals strong influence from his work as translator and reader of oriental literature. His most famous work, Kindertodtenlieder, which was set to music by Gustav Mahler, poetically embodies his grief for his two youngest children, who died of scarlatina. We bring here four of these poems in previously unreleased translation into Portuguese.

Keywords: Friedrich Rückert. Romanticism. Poetry.

RECEBIDO EM: 20 de setembro de 2019

ACEITO EM: 25 de novembro de 2019

PUBLICADO EM: março 2020 
$\mathrm{F}$ riedrich Rückert (1788-1866) foi um poeta e tradutor alemão. Nascido em Schweinfurt, publicou parte de sua obra sob o apropriado pseudônimo de Freimund Reimer, algo como "Boca-livre rimador", característica que se nota tanto em sua própria poesia quanto em sua vasta obra tradutória. Diz-se que dominava (em diferentes graus) 44 línguas, e traduziu sobretudo obras do persa, do turco e do árabe, entre elas o Shahnameh de Ferdusi e o Corão, ainda lida até hoje. Sua obra poética é divulgada sobretudo na forma de canções populares, e sua poesia é conhecida pelos Kindertodtenlieder - Canções de morte de crianças, escritas após a morte de dois de seus seis filhos, adoecidos de escarlatina. As Kindertodtenlieder - cinco delas - foram musicadas por Gustav Mahler no início do século XX. Traduzi aqui quatro canções diferentes das selecionadas por Mahler, para apresentar um contraponto às canções mais conhecidas e dar outros exemplos da potente poesia de Rückert.

In meine häuslichen Lieder,

Das Tagebuch meiner Lust,

Schrieb ich mit Freuden bewußt

Nur Freudengewinnste nieder,

Nie schrieb ich einen Verlust

In meine häuslichen Lieder.

In meine häuslichen Lieder

Schreib' ich nun euern Verlust

So hat sich schließen gemußt

Die Rechnung! und wohl nicht wieder

Schreib ich sobald eine Lust

In meine häuslichen Lieder.
Nas minhas canções caseiras,

O diário do meu prazer,

Anotei feliz, a saber,

Apenas faturas faceiras,

Nunca anotei um perder

Nas minhas canções caseiras.

Nas minhas canções caseiras

Agora inscrevo o vosso perder

E fechada teve que ser

A conta! e dessa maneira

Não mais anoto um prazer

Nas minhas canções caseiras. 
Du bist ein Schatten am Tage, És uma sombra de dia, Und in der Nacht ein Licht; $\quad$ E de noite um clarão;

Du lebst in meiner Klage, Vives nesta litania,

Und stirbst im Herzen nicht. Não morres no coração.

Wo ich mein Zelt aufschlage, Onde minha tenda se abria,

Da wohnst du bei mir dicht; $\quad$ Vives comigo, à mão;

Du bist mein Schatten am Tage, És minha sombra de dia,

Und in der Nacht mein Licht. De noite meu clarão.

Wo ich auch nach dir frage, Onde de ti inquiria,

Find' ich von dir Bericht, De ti ouvi narração,

Du lebst in meiner Klage, Vives nesta litania,

Und stirbst im Herzen nicht. Não morres no coração.

Du bist ein Schatten am Tage, És uma sombra de dia,

Doch in der Nacht ein Licht; $\quad$ Mas de noite um clarão;

Du lebst in meiner Klage, Vives nesta litania,

Und stirbst im Herzen nicht. Não morres no coração. 
Ein Jahr ist nun geschwunden,

Seit du geschieden bist,

Und wie zwei trübe Stunden

Gemahnt mich diese Frist.

Und hättest du gelebet,

Mein Kindchen, dieses Jahr,

So wär' die Frist entschwebet

Ein helles Stundenpaar.

Nun, seit ich auf der Bahre

Dich mußte sehn, mein Kind,

Denk' ich, wie wenig Jahre,

Verliehn dem Menschen sind.
Passou-se um ano agora

Desde que tu partiste.

E qual duas turvas horas

Este prazo me põe triste.

Se tu tivesses vivido

Este ano, minha cria,

O prazo teria fugido:

Duas horas de alegria.

Ora, dês que no caixão

Te vi, tão poucos anos,

Filho, cogito que são

Dados aos seres humanos.
Ob trüber oder heller,

Wie Stunden sind sie nur,

Ob langsamer, ob schneller,

Entschwunden ohne Spur.

Einst wünscht' ich langes Leben,

Um lang' dich blühn zu sehn;

Nun mag es schnell entschweben,

Da ich dich sah vergehn.

Im Verluste zu gewinnen,

Ist ein schwieriges Beginnen,

Und gelinget andern nie,

Als der Lieb' und Poesie.

Liebe läßt sich nichts entrinnen,
Se claras ou trevosas,

Horas são todas iguais,

Se ágeis ou vagarosas,

Somem assim, sem mais.

Já quis ter vida comprida

Para te ver florescer;

Que agora fuja fugida

Pois te vi fenecer.

Na perda poder ganhar:

Eis um duro começar,

E nenhures chegaria

Do que ao amor e à poesia.

O amor nada deixa escapar, 
Hat nicht außen, sondern innen;

Und das Nichts, sie weiß nicht wie,

Macht zum Etwas Poesie.

Nicht dahin ist, was von hinnen,

Bleibt im Sinn, nicht in den Sinnen;

Fest auf ewig halten's die

Beiden, Lieb' und Poesie.
Não tem fora, só dentro há;

E o nada - ele não sabia -

Faz do algo poesia.

Não se foi o que vem de lá,

Fica na mente, não no pensar;

Eterno preso seria

Por ambos: amor e poesia.

*Daniel MARTINESCHEN - Bacharelado em Ciência da Computação (2003) e Bacharelado em Letras PortuguêsAlemão, com ênfase nos Estudos da Tradução (2014) pela Universidade Federal do Paraná. Mestre em Informática (2006) e Doutor em Estudos Literários (2016) pela mesma instituição. Tradutor juramentado para o idioma alemão desde 2012. Professor Adjunto A1 da Universidade Federal de Santa Catarina, Centro de Comunicação e Expressão, Departamento de Língua e Literatura Estrangeiras. Florianópolis, Santa Catarina, Brasil.

Currículo acadêmico: http://lattes.cnpq.br/9682846387047730

ORCID: https://orcid.org/0000-0002-2909-1861

E-mail: daniel.martineschen@ufsc.br 